\author{
HELIA BONILLA
}

\title{
Las indagatorias en torno a una caricatura denunciada en 1829
}

$\mathrm{E}$ N POCAS OCASIONES PODEMOS reconstruir siquiera algunos de los hechos que circundaron la producción y circulación de imágenes de carácter satírico (y, en realidad, de cualquier tipo de ilustración) en las primeras décadas del México postindependiente. Tampoco es frecuente que podamos enterarnos de quiénes fueron sus autores. En este sentido, el expediente que en seguida se transcribe, y que se ha conservado en el Archivo Histórico y Memoria Legislativa de la Cámara de Senadores, ${ }^{\mathrm{I}}$ ha guardado incidentalmente valiosa información para la posteridad. Desde nuestra propia ubicación temporal, no queda sino agradecer a quien decidió hacer la denuncia de la estampa en torno a la que gira el citado expediente, enviándola a las autoridades eclesiásticas para que éstas a su vez —en una época en que la censura estaba ya en manos de la autoridad civil — la hicieran llegar al gobernador del Distrito Federal. El argumento fue que en ella se representaban irónicamente los progresos o el estado actual de la república mexicana. ${ }^{2}$

I. Archivo Histórico y Memoria Legislativa de la Cámara de Senadores (en adelante AHyML). Congreso 3, lib. I7, ff. 55-73 en la foliación hecha con sellos, y I-I9 en la foliación manuscrita; esta última sólo atañe al expediente que aquí se revisa, y no al resto de los que componen el volumen. Por cuestiones de error en la foliación (véase al respecto la nota 47), aclaro de una vez que en las citas preferí utilizar justamente la foliación manuscrita. Por otra parte, quiero agradecer ampliamente a María José Esparza su valiosa y atenta ayuda en las correcciones sobre mi transcripción inicial del expediente.

2. Ibid., ff. IIr y I2r. 
Antes de abordar el expediente, conviene hablar un poco sobre la imagen ${ }^{3}$ (fig. I). Aunque fue remitida sola, como lámina suelta, originalmente había aparecido inserta en El Toro, impreso periódico del que adelante se habla. Ilustraba una parte del texto titulado "Siguen las hijas del Cojo retozando en el Parián: Diálogo tercero entre un cohetero y un tamborilero", el cual estaba fechado el I5 de julio de I829. El texto, junto con los anteriores publicados en el citado periódico, hicieron terrible escarnio del grupo político de los yorkinos, el cual, para hacerse del poder, había organizado el motín de la Acordada que en I828 concluyó con la destrucción del Parián, es decir una de las movilizaciones más violentas del periodo, que marcaría de forma indeleble el imaginario de la generación que lo presenció directa o indirectamente. Con un lenguaje coloquial y popular, y aun soez, el texto señaló algunos de los supuestos abusos cobijados por el ilegítimo gobierno de Vicente Guerrero y por varios de sus colaboradores. Entre ellos, estaría el de distraer continuamente a la población con la falsa noticia de un intento de reconquista por parte de España. Como en textos anteriores de El Toro, en una parte de éste se acudía a una añeja tradición de la literatura occidental que, aunque tal vez caduca en Europa, continuaba vigente en la prensa mexicana del periodo: la del sueño literario, en donde el narrador, identificado a menudo con el protagonista, tiene un sueño en el que se le revelan verdades trascendentes. ${ }^{4}$ En el sueño se hacía una parodia de la actuación de los legisladores yorkinos, quienes aparecían como prostitutas (con apodos gracias a los cuales eran claramente reconocibles sus nombres) jugando al Congreso en un jacalón donde, bajo un dosel, estaba colocada una pintura que era a su vez una parodia del escudo nacional. Fue justamente esa representación paródica la que se mostró en el grabado. Es difícil decir si quien escribió el texto, al subvertir el simbolismo original, tuvo presente alguna imagen específica del flamante emblema mexicano (el país, recién independizado, estrenaba símbolos nacio-

3. Ha sido comentada someramente en diversos estudios sobre caricatura. Manuel Toussaint, "The Political Caricature in Mexico", en Mexican Art and Life, México, DAAP, núm. 4, octubre de 1938; Rafael Barajas (El Fisgón), La historia de un país en caricatura: caricatura mexicana de combate: $1829-1872$, México, Consejo Nacional para la Cultura y las Artes, 2000, pp. I32 y I33, y Helia Bonilla, "La gráfica satírica y los proyectos políticos de nación: (I808-1857)", en Los pinceles de la historia: de la patria criolla a la nación mexicana: 1750-1860, México, Museo Nacional de Arte/Universidad Nacional Autónoma de México-Instituto de Investigaciones Estéticas, 2000, pp. $177-178$.

4. De hecho, varias caricaturas mexicanas del periodo ilustran textos insertos en dicha tradición; véase al respecto Helia Emma Bonilla Reyna, "El Calavera: caricaturas en tiempos de guerra", Anales del Instituto de Investigaciones Estéticas, vol. XXIII, núm. 79, otoño de 200I, pp. IO4-IO6. 
I. Caricatura al aguafuerte que ilustra el artículo "Siguen las hijas del Cojo retozando en el Parián. Diálogo tercero entre un cohetero y un tamborilero", en José Mariano Torreblanca, El Toro, México, Imprenta del ciudadano Alejandro Valdés, Is de julio de I829. La imagen está inserta en Congreso 3, lib. I7, f. I (en la foliación manuscrita), Archivo Histórico y Memoria Legislativa de la Cámara de Senadores.

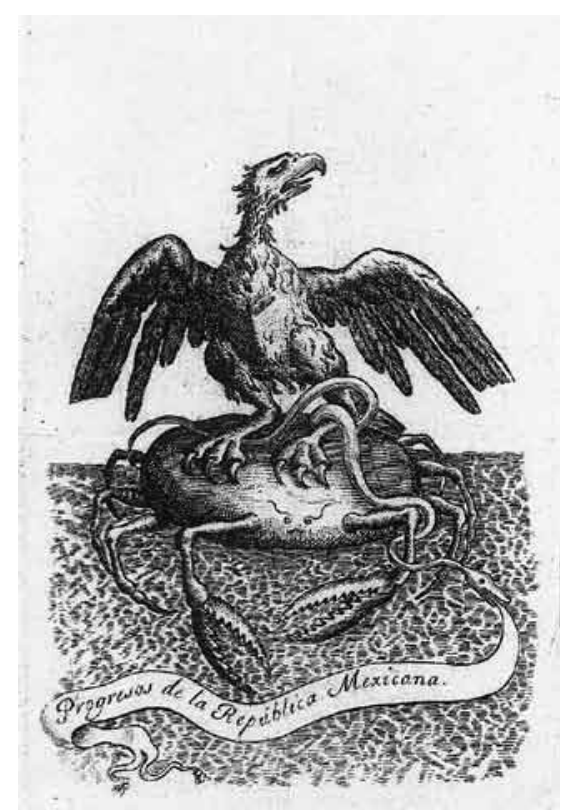

nales), aunque es posible que el propio Torreblanca, para hacer la caricatura, sí tuviera en mente alguna de las variantes que, con dicho motivo, había realizado para distintas dependencias del gobierno ${ }^{5}$ o, por ejemplo, la más llamativa que hizo específicamente para la portada del cuadernillo en que se plasmó la Constitución de 1824 (fig. 2). Como haya sido, la propia narración fue la que dio pauta al dibujante para que trastocara el emblema; en ella, Cuajo largo —el personaje de escatológico nombre que era quien soñaba - se negaba a reconocer en la pintura "las armas de la nación”, pues, en vez de una productiva laguna, veía un estéril arenal; en vez de un nopal lleno de dulce y benéfico fruto, un seco cangrejo que caminaba hacia atrás, y un águila que, en lugar de estar parada en una pata y sostener con la otra a la serpiente símbolo de la discordia y del mal, estaba plenamente asentada sobre el cangrejo, desplumada y con las alas cortadas, y que con sus patas enlazaba la susodicha serpiente con el cangrejo; del hocico del

5. Al respecto, véase Carrera Stampa, El escudo nacional, México, Secretaría de Hacienda y Crédito Público, 1960. Citado en María José Esparza Liberal, "Los calendarios y la gráfica decimonónica como expresión del acontecer político y social en México, I82I-I850”, tesis de maestría en historia del arte, México, Universidad Nacional Autónoma de México-Facultad de Filosofía y Letras, 20oI, p. 47. 
reptil salía una cinta con la irónica frase "Progresos de la república mexicana" . ${ }^{6}$ La imagen, en suma, mostraba las perspectivas del país bajo el nuevo y, desde su punto de vista, espurio gobierno yorkino.

En cuanto al expediente, antes de hacer una primera aproximación, conviene señalar de manera general cuáles son los documentos o fases que lo componen (no interesa aquí discernir los pasos legales que debían seguirse en los juicios de imprenta): la orden de la autoridad competente al poder judicial para que investigue la procedencia de la lámina, la anexión de la propia estampa ${ }^{7}$ (hecha al aguafuerte) y las indagatorias realizadas, es decir la toma sucesiva de declaraciones al encargado de la imprenta de la que salió el impreso en donde la imagen se insertó y al propio grabador, y la anexión del susodicho impreso. Posteriormente, las decisiones contrapuestas - y manifiestas en los documentos- entre las instancias competentes respecto a si había delito o no, la orden de formalizar el proceso, la petición al redactor del impreso (probable comitente de la obra a quien se terminó considerando autor de la imagen) de que diera fiador de su persona, la toma de su declaración y, finalmente, la constatación de su fuga para evadir las responsabilidades que pretendían fincársele.

Es claro que no todas las decisiones y comunicaciones que se sucedieron en torno al hecho quedaron plasmadas en el expediente. Por ejemplo, la decisión de que se procediera a formalizar el caso, tomada en la Suprema Corte de Justicia, únicamente fue comunicada al juez inferior, pero al menos en los documentos resguardados no quedó constancia de las deliberaciones de sus miembros para que así ocurriera, lo que nos impide conocer la razón jurídica para que se continuara el procedimiento. ${ }^{8}$ Se puede suponer que quizá también hubo comunicaciones verbales entre las diferentes instancias (quizá Tornel, gobernador del Distrito Federal, se haya puesto en contacto con las altas esferas del poder judicial para que contravinieran la orden del juez inferior respecto a cerrar el caso).

Por otra parte, es probable que los declarantes hayan dado información que no fue registrada en los expedientes. Así, cabe suponer que fue José María Galle-

6. "Siguen las hijas del Cojo retozando en el Parián: diálogo entre un cohetero y un tamborilero", en El Toro, México, Imprenta del ciudadano Alejandro de Valdés, Is de julio de i829, p. 5. 7. Llama la atención que no se encuentre acuareleada, a diferencia de la que se conserva en el volumen de El Toro de la Hemeroteca Nacional. Se ha dicho que a veces son los libreros quienes llegan a iluminar estampas que originalmente no lo estaban para venderlas a un precio mayor.

8. Cabe pensar que algunos documentos, tanto de los que sí como de los que no se acusó recibo, hayan quedado en las citadas instancias, por ejemplo en el Gobierno del Distrito Federal o en la Suprema Corte de Justicia. 
2. Portada de la Constitución de I824, aguafuerte, México, Imprenta del Supremo Gobierno de los Estados Unidos Mexicanos en Palacio, I824. Colección particular. Tomado de Brian R. Hamnett et al., Juárez: Memoria e imagen, México, Secretaría de Hacienda y Crédito Público, 1998, p. 46.

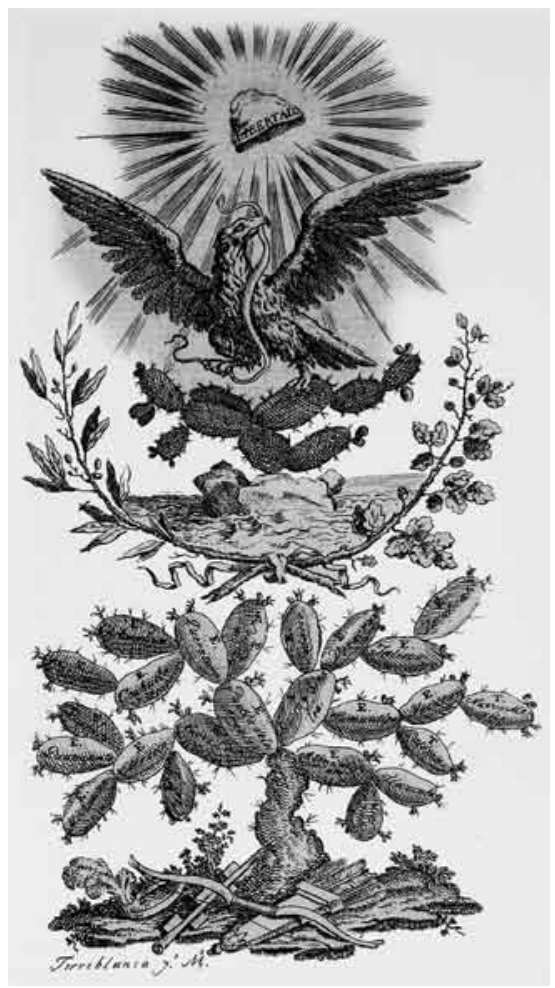

gos, el encargado de la imprenta en donde se había imprimido el periódico $E l$ Toro (y en cuyo tercer número se había insertado el aguafuerte que pretendía ser juzgado), quien dio un ejemplar de dicho impreso al juez de letras que lo interrogó, si bien en los documentos no se hizo constar en dónde se recogió. También es probable que de manera informal, y quizá sólo como sugerencia, haya sido él quien diera el nombre del grabador que había abierto la lámina, aunque en su declaración formal hubiese dicho que el único que podría saber esto era Rafael Dávila, autor de El Toro o Torito. Cabe suponer esto porque, el mismo día que el juez y el escribano lo visitaron y llevaron a cabo la averiguación, interrogaron también al grabador José Mariano Torreblanca, quien resultó ser efectivamente quien la hizo. ${ }^{9}$ Resulta difícil saber si éste, luego de admitir ser el ejecutor del

9. Pudo ocurrir, sin embargo, que ambos funcionarios visitasen a otros grabadores, y que, ante la negativa, no hicieran registro de sus declaraciones por falta de utilidad para el caso. 
aguafuerte, dio al juez de letras la dirección de Rafael Dávila. Lo que sí se puede determinar es que el mismo día, I9 de agosto de I829, el grabador avisó al panfletista lo que había declarado al funcionario, según admitió el propio Dávila en su posterior declaración. De seguro la noticia de Torreblanca le dio al escritor oportunidad de prepararse para la entrevista, y quizá también para la huida.

Los documentos a la mano provocan sospechas por el momento insolubles. Cabe preguntarse, por ejemplo, si efectivamente fueron tantos los involucrados en la denuncia de la imagen. Es decir, si fue el obispado de Puebla el que la mandó sin carta que la acompañase al gobernador del estado, quien luego la enviaría al Ministerio de Relaciones, para que éste a su vez la remitiera al gobernador del Distrito Federal, José María Tornel. Si así fue, el destino era el correcto, porque la imagen originalmente ilustraba un número de El Toro, periódico salido de una conocida imprenta de la ciudad de México: la de Alejandro Valdés. La duda de que la imagen hubiese seguido ese periplo surge porque el Torito - como familiarmente solía llamársele al periódico producido por Rafael Dávila- era bien conocido en el ámbito de la opinión pública (venía saliendo desde hacía dos o tres años atrás ${ }^{\mathrm{I}}$ ), que sabía quién era su autor, a pesar de que en el impreso no se daba su nombre. En este sentido, valga citar aquí al historiador Carlos María de Bustamante, el cual anexó en su Diario el grabado y escribió el 29 de julio de I829 lo que sigue:

Hoy se ha publicado la adjunta caricatura que representa una águila desplumada, colocada sobre un cangrejo y es símbolo de la pobre República Mexicana. Pertenece a la descripción que de nuestra miseria actual hace Rafael Dávila en uno de sus números del Toro, que está publicando al parecer en buen sentido; mucho ha dado que reír, y no es poca la impresión que ha hecho en el pueblo de México. Tal es el efecto mágico de las caricaturas. ${ }^{\text {II }}$

Io. Sobre el historial de esta publicación, véase Miguel Ángel Castro y Guadalupe Curiel (coords.), Publicaciones periódicas mexicanas del siglo XIX: I822-I855, México, Universidad Nacional Autónoma de México-Instituto de Investigaciones Bibliográficas, 2000, pp. 423-425 y 432-433.

II. Carlos María de Bustamante, Diario histórico de México (I822-I848), Josefina Zoraida Vázquez y Héctor Cuauhtémoc Hernández Silva (eds.), CD rom, México, Colegio de México-Centro de Investigaciones y Estudios Superiores en Antropología Social, 200I, vol. I. Véase el día 29 de julio de I829. Por cierto, llama la atención que, como se indicó, el impreso tenga fecha del is de julio y que Bustamante señale que se publicó hasta el día 29 del mismo mes; quizá la fecha no corresponde al día de publicación, sino más bien al día en que el texto fue escrito. 
Por lo tanto, independientemente de que Bustamante no siempre se expresó bien de Dávila (llegó a decir que era "malvado", "tunante" y "autor gandul que come de lo malo que escribe" ${ }^{2}$ ), es más que probable que José María Tornel no requiriera ser informado sobre la existencia de la imagen. Esto, porque él y su grupo (la logia yorkina), desde la reaparición de El Toro (cuya circulación había sido suspendida en diciembre de $1828^{13}$ ), fueron el blanco principal y explícito de los ataques del panfletista, quien hizo acre escarnio de sus acciones y triunfo a partir del tristemente célebre motín de la Acordada. Así que, al margen de que era a Tornel a quien, por ser gobernador del Distrito Federal, correspondería denunciar los abusos de libertad de imprenta y declarar si un impreso era susceptible de formación de causa o no, ${ }^{14}$ es muy posible que tras el intento de proceso se encontrara sobre todo un deseo de revancha y acallamiento. Además, en particular, a Tornel le importaba bastante lo que de él se decía en público, al grado de que un año atrás había insultado y maltratado personalmente al autor de un folleto en el que se le atacaba. ${ }^{5}$ Pero, aun más, es posible que con respecto a Dávila la molestia fuera doble, pues por lo menos entre bastidores se decía que poco antes el panfletista había estado precisamente al servicio del propio Tornel, quien pagaba a éste con dinero "del fondo de multas que estaba aplicado a beneficio de obras piadosas como el Hospicio, Enseñanza de Industrias, etc."I6 Según testimonio posterior de Dávila, en I829 "los del triunfo de la Acordada" incluso intentaron asesinarlo cinco veces. ${ }^{17} \mathrm{Al}$ final, si bien Tornel no consiguió detener a Dávila porque éste se escabulló, sí consiguió que suspendiera su publicación, la cual sólo pudo reaparecer cuando el cuestionado gobierno de Vicente Guerrero, con el que Tornel colaboraba, fue desplazado del poder.

Quedan apuntados cuáles pudieron ser los intereses políticos que se movieron y cuál el objetivo de la denuncia. En cuanto al tema que más interesa aquí, esto es, las imágenes, conviene señalar, según está demostrado ya, que en México fue la panfletografía vehículo principal de la caricatura en estos años, ${ }^{18}$ y que

I2. Ibid. Véanse 23 de marzo de 1828 y 6 de noviembre de 1829 .

13. Castro y Curiel, op. cit., p. 424.

I4. Por lo menos un año antes, por ocupar ese cargo, era ésta una responsabilidad de Tornel. María del Carmen Vázquez Mantecón, La palabra del poder: vida pública de José María Tornel (I795-1853), México, Universidad Nacional Autónoma de México-Instituto de Investigaciones Históricas, I997, p. 57.

I5. La amena descripción del flagrante hecho se encuentra en ibid., pp. 59 y 60.

I6. Bustamante, op. cit. Véase 23 de marzo de I828.

17. Castro y Curiel, op. cit., p. 433.

I8. Bonilla, "La gráfica satírica...", op. cit., pp. I70-187. 
El Toro, a pesar de ser una publicación con una determinada periodicidad, ${ }^{19}$ es considerado un panfleto, y su autor, uno de los más importantes panfletistas. ${ }^{20}$ Rafael Rojas, sin referirse a ninguna imagen, ha estudiado las características de estas publicaciones y de sus autores, $y$ en este sentido el expediente sirve para demostrar varios de sus asertos: confirma la marginalidad cultural y económica en que se insertaron los panfletistas y sus publicaciones, y la penetrabilidad de los panfletos sobre el ámbito de lo que Rojas llama la notabilidad social. ${ }^{21}$ Es decir, que la elite no sólo estaba al tanto de estas producciones que, en el caso de las de Dávila, además de un lenguaje vulgar tenían un tono francamente escatológico, sino que seguramente las leía (hay que recordar, en última instancia, que era ella la que a veces las financiaba y se beneficiaba de sus efectos)..$^{22}$ La contextualización histórica y la forma en que se hicieron las pesquisas indica, como ya se señaló, que desde un principio las autoridades estarían bien enteradas no sólo de quién era el redactor del panfleto del que la imagen formaba parte, sino de cuál era la imprenta que los había sacado a la luz. Cuando Tornel da la orden de que se averigüe quién fue el autor del grabado, indica directamente que se vaya a la imprenta de Alejandro Valdés. Es casi seguro que desde que dio esta orden estaba pensando en atajar de una vez por todas el camino a Dávila.

Pero el expediente no sólo confirma algunos supuestos sobre los ámbitos culturales en que las imágenes se movieron, pues también da pistas sobre los ámbitos espaciales. Si efectivamente - aunque sólo como pretexto-, la estampa hubiese sido remitida de Puebla, tendríamos un indicio sobre las rutas de distribución de la exigua producción caricaturística de la capital en la primera década de vida independiente. Por cierto, se sabe que Puebla tuvo un desarrollo propio e importante de gráfica e imprenta, ${ }^{23}$ y por ello no resulta extraño que

19. En general, a lo largo de los años ésta varió y apareció sucesivamente una, dos o tres veces por semana, aunque en la etapa que nos ocupa su periodicidad fue semanal. Castro y Curiel, op. cit., pp. 423 y 432.

20. Rafael Rojas, "Una maldición silenciada. El panfleto político en el México independiente”, en Historia Mexicana, México, vol. XLVII, núm. I, julio-septiembre de 1997.

2I. Idem.

22. El comentario de Bustamante, citado más arriba, también da prueba de todo esto.

23. De hecho, entre la escasa producción hasta ahora localizada hay al menos otra imagen satírica que fue producida probablemente por un grabador poblano, puesto que el panfleto en que apareció se publicó justamente en Puebla. Se trata de la imagen que ilustra el folleto Premio de los americanos por gachupines y frailes. Diálogo entre el padre Arenas, el general Arana y don Agustín de Iturbide, publicado en 1827 . La reproduzco en Bonilla, "La gráfica satírica...", op. cit. 
José Mariano Torreblanca, el grabador de la imagen en cuestión, fuese precisamente poblano (este y otros datos biográficos se corroboran en el propio expediente, que también aporta algunos nuevos).

Conviene aclarar que fueron pocas las ocasiones en que los folletos estuvieron ilustrados, y por ello interesa este conjunto de documentos, pues el motivo o pretexto principal de la persecución es justamente una de esas escasas imágenes. Pero, además, interesa porque en él se expresan las voces de las tres instancias que participaron, o llegaron a participar, en la producción de los panfletos, proporcionándonos informaciones escuetas, aunque interesantes, sobre cada una de ellas: la del impresor, la del panfletista o redactor y la del grabador. Haremos aquí algunas someras observaciones de lo que en relación con cada una se desprende de las declaraciones.

En general, y aunque algunos ya se conocían, el expediente ofrece escuetos datos biográficos de los tres declarantes (véase el expediente, que al final se reproduce en esta noticia bibliográfica). En lo que se refiere a Rafael Dávila, muestra las responsabilidades y la vida marginal que, en efecto, los panfletistas se veían obligados a enfrentar. En este sentido, se ha señalado ya que muy probablemente fue la virulenta oposición del escritor a los yorkinos lo que desató la persecución en su contra. Teniendo a Dávila en la mira, y enterado Tornel de que él había sido quien encargó la estampa, asentó a las claras que aquél era su autor. Sin embargo, ni él ni otra autoridad argumentaron en términos jurídicos la transgresión cometida con la imagen, ni aclararon por qué era ella, y no el corrosivo escrito, la que debía ser juzgada. Avisado de antemano por Torreblanca, y conociendo el reglamento de libertad de imprenta, Dávila trató de defenderse y ganar tiempo; negó ser el autor de El Toro y de la imagen (dijo que más bien trabajaba para dicho autor), apeló respecto al hecho de que se violentasen los mecanismos legales para hacerle declarar quién era el verdadero autor y pidió una orden por escrito para su resguardo legal (independientemente de que en este caso fuese cierto, parece ser que efectivamente Dávila no siempre fue autor de los textos que firmaba). ${ }^{24}$ Se le respondió que el privilegio de no indagar quién era el autor recaía "sólo sobre escritos impresos, y no sobre láminas, ${ }^{25} \mathrm{ni}$ caricaturas", pero Dávila se sostuvo y argumentó que el verdadero autor — que lo era igualmente de El Toro- no había:

24. Bustamante, op. cit. Véase el 3I de marzo de I829.

25. AнумL. Congreso 3, lib. I7, f. I7r. 
hecho otra cosa que seguir el ejemplo de todos los autores que abren láminas de lo más notable de sus obras a los que jamás se les ha juzgado por separado las láminas de sus escritos, por lo que, y en atención al artículo ya citado de la ley de libertad de imprenta, no se cree obligado el que habla a declarar quién es el autor de dicha lámina, y por lo mismo, apela (hablando debidamente) de este apercibimiento. ${ }^{26}$

Al día siguiente, cuando se quiso continuar con el procedimiento y quizá recoger el nombre del fiador de su persona, el escribano fue informado de que el escritor no se encontraba en el lugar y que no tenía un domicilio fijo. Esto último da cuenta justamente de la condición de marginalidad en que los panfletistas vivieron, asediados por los odios políticos y por una inestable situación económica y laboral. Pocos años después, y ante la dificultad de la policía para ubicarlos, se emitió un bando que prohibía que fueran responsables de las publicaciones vagos, sentenciados, presos, enfermos consuetudinarios residentes en hospitales y hombres cuya morada y modo de vivir fuese desconocido. ${ }^{27}$ Por lo visto, la táctica de Dávila era común a los panfletistas.

En cuanto a la información que respecto del impresor aporta el expediente, se debe aclarar que en realidad no se entrevistó directamente a Alejandro Valdés, ${ }^{28}$ el dueño de la imprenta en donde se imprimía El Toro - la más importante de la ciudad de México en estos años- ${ }^{29}$ sino al responsable de ella, José María Gallegos, quien, luego de trabajar en otras empresas editoriales, había llegado a la de Valdés en I828..$^{30}$ En su declaración, Gallegos deslindó a la imprenta de Valdés respecto de la imagen, dijo que Dávila había traído las estampas ya impresas y que pidió que se insertaran en el número correspondiente del Torito, y que por lo tanto él sería quien sabría quién había abierto la lámina. De lo dicho por Gallegos se desprendería, por ejemplo, que la imprenta más próspera de la capital no contaba con tórculo para imprimir aguafuertes, ${ }^{3 \mathrm{I}} \mathrm{y}$ que éstos se encon-

26. Idem.

27. Rojas, op. cit., p. 64.

28. Se puede encontrar una reseña general sobre la trayectoria del impresor en María José Esparza Liberal, op. cit., pp. 49 y 50.

29. Nicole Giron, "El entorno editorial de los grandes empresarios culturales: impresores chicos y no tan chicos en la ciudad de México", en Laura Beatriz Suárez de la Torre (coord.), Miguel Ángel Castro (ed.), Empresa y cultura en tinta y papel (I800-I860), México, Instituto de Investigaciones Dr. José María Luis Mora/Universidad Nacional Autónoma de México, 200I, p. 54.

30. Gallegos permanecería ahí diez años más; idem.

31. Gallegos dijo, por tanto, que era tarea distinta la de imprimir que la de grabar láminas; esto, porque las prensas para imprimir tipografía y para imprimir grabados eran diferentes. Ello signi- 
traban en un negocio especializado: el de las "oficinas" - como entonces se les llamaba - de los grabadores. Sin embargo, esta respuesta plantea varias dudas. Valdés contaba con una cierta provisión de grabados en relieve (probablemente xilografías) con que ilustraba diversos impresos de literatura popular, aspecto que también lo destaca entre los editores de estos años; ${ }^{32}$ lo anterior implica que sabía el encanto que ejercían las imágenes, por toscas que fueran, entre el público consumidor. De hecho, en años anteriores, el impresor, al igual que lo habían hecho durante siglos muchas imprentas del periodo colonial, y como continuarían haciéndolo muchas después de la Independencia, se allegó recursos valiéndose de la imaginería religiosa; para ello, aunque no sabemos qué tan a menudo, Valdés llegó a utilizar, antes y después de I829, láminas al aguafuerte. ${ }^{33}$ Por lo tanto, y considerando que la estampería y los impresos de carácter religioso fueron una fundamental fuente de recursos para muchas imprentas, que usaban y reutilizaban sus imágenes, es posible que Gallegos no hubiese dicho la verdad cuando afirmó que no existían en la imprenta láminas, sino únicamente escudos. ${ }^{34} \mathrm{De}$ ser así, quizá lo que en realidad pretendía era ocultar alguna o algunas láminas que no convenía que vieran los enviados del gobierno. Como sea, y para terminar este párrafo, interesa comentar que no es fácil discernir la posición política que, como impresor, pudo asumir Valdés, pues, a lo largo del tiempo, los impresos que salieron de sus negocios sostuvieron diversas y a veces contradictorias posturas políticas, lo cual se explica porque a menudo los impresores ofrecían sus servicios a quien lo solicitara, sin que ello significara suscribir sus opiniones. ${ }^{35}$ Interesa

ficaría que en la imprenta de Valdés no había prensa o tórculo para sacar copias de grabados al aguafuerte.

32. En los microfilmes de la Sutro State Library, que se encuentran en el Instituto de Investigaciones Históricas, es en donde he podido enterarme de este hecho.

33. En I820, por ejemplo, ilustró un impreso con un aguafuerte de tema religioso (véase en la colección de microfilmes citada en la nota precedente, rollo núm. 44 PM. soc-soT) y lo hizo de nuevo en 1828, en este caso firmado por Navarro (véase rollo núm. 32 PM. NUN-OLV). Aunque se trata de un ejemplo posterior, se puede señalar que en 1833 publicó otro, también de tema religioso, firmado por un tal Zapata (rollo núm. 34 PM. OVI-PAY).

34. La imprenta podía contar con imágenes al aguafuerte, sin necesariamente tener que contar con un tórculo, pues podría eventualmente pagar a alguien que tuviera la maquinaria necesaria para que se las imprimiera. Como sea, por ahora resulta difícil descubrir lo contrario. Por otra parte, Gallegos no aclaró la técnica aplicada en los escudos con que, según él, contaba la imprenta.

35. Esparza, op. cit., p. 50. Impresos salidos del negocio de Valdés, sucesivamente, atacaron a los insurgentes, apoyaron el imperio de Iturbide y atacaron a los escoceses y a los yorkinos. 
también señalar que, entre la muy escasa producción de estampas satíricas que circularon durante la época, hay al menos otras tres que salieron de la imprenta de Valdés, ${ }^{36}$ una de las cuales, por estar grabada en relieve (madera o quizá plomo), se imprimió sin duda en dicha casa junto con el texto que ilustraba. ${ }^{37}$

Una cuestión puntual sobre la que informa el expediente es el costo que tuvo la imagen, y que fue de diez pesos. Era bastante alto, considerando que hacia I840, con un peso y medio (I2 reales), se podía comprar un pavo, y que al mes una recamarera ganaba cerca de cuatro pesos, y un portero, un cochero y una costurera, quince. ${ }^{8}$ Se ha señalado ya el alto costo que años atrás, en I8or, tuvieron las $5 \mathrm{I}$ imágenes que al aguafuerte realizó Montes de Oca para la Vida de san Felipe de Jesús, por las que cobró I or3 pesos, ${ }^{39}$ es decir 19.06 pesos en promedio. Sin embargo, el precio comprendía la retalla de las placas, puesto que, por el largo tiraje ( un retoque. Quizá ello haya influido para que dichas imágenes costaran el doble que la de Torreblanca. En todo caso, si éste cobró aparte el tiraje (pues, además del arduo trabajo que implicaba la impresión de una plancha al aguafuerte, se requería un papel especial, que de por sí era caro, y más por ser de importación), tal vez Dávila haya pagado aún más.

Lo anterior permite vislumbrar algo sobre el nivel de vida de este grabador en particular. Aunque Torreblanca señaló que su sueldo era insuficiente, el que

36. Hacia 1822 o principios de 1823 , Valdés, quien entonces fungía como impresor oficial del efímero imperio de Iturbide, publicó una interesante caricatura con los versos titulados Por Victoria, devoto anacoreta, triunfó Agustín de todo vil chaqueta. El 3I de diciembre de I824, publicó un panfleto del Payo del Rosario que también tenía una caricatura y que se titulaba El quitasol, y hacia I827 otro titulado Gran logia Nación Mexicana, y pira de los yorkinos. Dos de las imágenes se reproducen en Bonilla, "La gráfica satírica...", op. cit., pp. I75 y 177, pero la ficha de las tres se encuentra en el catálogo de la obra que aparece al final del libro en que se encuentra el artículo, con los números 182, 163 y I69, respectivamente.

37. Me refiero a la que ilustra el panfleto del Payo del Rosario, titulado El quitasoly citado en la nota anterior.

38. Esparza Liberal, op. cit., p. 39. La autora toma la información de un apéndice sobre precios de productos y servicios del libro de Brantz Mayer titulado México: lo que fue y lo que es. Véase también María Esther Pérez Salas, "Los secretos de una empresa exitosa: la imprenta de Ignacio Cumplido", en Laura Suárez de la Torre (coord.), Constructores de un cambio cultural: impresores-editores y libreros en la ciudad de México: 1830-I855, México, Instituto de Investigaciones Dr. José María Luis Mora, 2003, p. I45. Pérez Salas, por su parte, se basa en datos que ofrece madame Calderón de la Barca.

39. Ibid., p. 45. Se recoge la información de un artículo de Dorothy Tanck. 
recibía de la Casa de Moneda no era tan bajo para una persona de clase media, ${ }^{40}$ pues en esta época, anualmente, su salario ascendía a mil pesos (en I833 esa cantidad se duplicaría), ${ }^{41}$ es decir que ganaba 83.3 pesos mensuales, lo que lo pone muy arriba de los salarios de los trabajadores arriba citados. Por otra parte, el hecho de contar con un cargo en la burocracia (aspiración de buen número de ciudadanos de la época) debió quizá darle alguna tranquilidad, si es que no se vio afectado como muchos de los empleados del gobierno por pagos extremadamente impuntuales.

Para concluir con la instancia correspondiente al grabador, cabe señalar que el expediente permite conocer cuál fue el papel de Torreblanca en la realización de la caricatura: él simplemente recibió las instrucciones y un pago por realizarla. Él mismo, para deslindarse de la autoría de la imagen, afirmó que Dávila se la había encargado y argumentó que como artesano no le alcanzaba su sueldo de grabador principal de la Casa de Moneda (cargo que ocupaba desde i 827 y en el que continuaría al menos hasta i84I), ${ }^{42}$ y que por ello, entre las varias obras que le llevaban "de la calle, cogió el de hacer la lámina". ${ }^{43}$ Con esto, explícitamente admitió que recibía encargos distintos, lo cual se puede corroborar porque una relativa cantidad y variedad de grabados suyos al aguafuerte han llegado hasta nuestros días en diversos tipos de impresos (encabezando periódicos, en obras literarias de Lizardi, en calendarios, etc.). Es posible que Torreblanca haya sido también ejecutor de otras de las imágenes satíricas del periodo, pero, a menos que aparezca alguna otra noticia incidental, será difícil que lo sepamos, porque todas fueron anónimas.

40. Para comparar, véase Michael P. Costeloe, La República central en México, I835-1846: "Hombres de bien" en la época de Santa Anna, México, Fondo de Cultura Económica, 2000, pp. 35-36.

4I. El Mosquito, México, t. II, núm. 93, I2 de febrero de I836, p. I.

42. Torreblanca había iniciado su colaboración con la Casa de Moneda desde 1809 y, luego de un tiempo de haber suspendido su colaboración, regresó en I823; El Mosquito, México, t. II, núm. 93, I2 de febrero de I836, p. I (aquí hay un recuento más amplio de su trayectoria en dicha institución). Una semblanza del grabador y su obra, construida a partir de fuentes bibliográficas fundamentales y de obras de índole diversa, se encuentra en Esparza Liberal, op. cit., pp. 46-47. A la información proporcionada por la historiadora, se puede añadir que en I84I Torreblanca continuaba como grabador de la Casa de Moneda, y que no había muerto en 1848, pues en ese año envió algunas pinturas para una exposición en la Academia de San Carlos. Al respecto, véase en Bustamante, op. cit., vol. 2, 2003, el día 2I de febrero de I84I, y "Exposición de la Academia Nacional de Bellas Artes de San Carlos”, en El Universal, México, t. I, núm. 46, 3 I de diciembre de I848, p. 3.

43. AнумL, Congreso 3, lib. 17, f. 5 v. 
Según Dávila, había encargado la imagen a Torreblanca porque era "el más hábil de los grabadores", lo que nos da un parámetro del nivel de calidad que tenían sus colegas del ámbito comercial y que, en opinión de un destacado contemporáneo como Carlos María de Bustamante, dejaba mucho que desear (para ilustrar algunas de las obras que editó, Bustamante mismo se vio en la necesidad de mandar a hacer grabados al extranjero). ${ }^{44}$ Por lo anterior, cabe pensar que desde entonces, y hasta mediados del siglo xIX, no existiría en México propiamente el oficio de caricaturista. Había, en cambio, ilustradores que vendían sus servicios y realizaban diversidad de imágenes; ellos, bajo la dirección de los panfletistas y periodistas, hicieron las caricaturas ${ }^{45}$ y, por lo tanto, éstas reflejaron casi siempre los intereses de quienes las encargaron. ${ }^{46}$

Por todo lo anterior, no extraña que los grabadores, y en este caso concreto José Mariano Torreblanca, no fuesen responsabilizados por el contenido de las imágenes. Se podría aducir que las autoridades gubernativas - Tornel en concreto- asumieron que el redactor del impreso era el autor de la imagen porque desde un principio querían ponerle la mano encima a Rafael Dávila; sin embargo, el propio periodista afirmó que el autor del texto era también el autor de la imagen, si bien se negó a reconocer que se tratase de él mismo.

[portada del expediente]

México año de 1829

N. $2^{\circ}$

Averiguación sobre el descubrimiento del que haya grabado la lámina de la estampa que sigue.

44. Diferentes comentarios al respecto se encuentran en Bustamante, op. cit., vol. I. Véanse los días 3 de julio de I823, 25 de enero de I827, II de noviembre de I83I y I7 de abril de I833. En esta última fecha comenta que por fin le llegaron "dos cajones de estampas venidas de Filadelfia para publicar la obra de antigüedades mexicanas del señor don Antonio León y Gama”.

45. Aunque esto empieza a perfilarse desde los años cincuenta, no es sino hasta la década de los años sesenta cuando se alcanza un grado de profesionalización y especialización entre los dibujantes, algunos de los cuales empezaron a dedicarse sobre todo a la caricatura. Es probable, además, que ya en esta época al menos algunos de ellos construyan las imágenes a partir de sus propias ideas (es muy posible, por ejemplo, que sea el caso de Constantino Escalante).

46. Esto ocurre, por ejemplo, en publicaciones incluso más tardías, como el periódico El Telégrafo o el libro El gallo pitagórico. Sobre el primero, véase el texto que publiqué en el núm. 8I de Anales del Instituto de Investigaciones Estéticas, Universidad Nacional Autónoma de México-Instituto de Investigaciones Estéticas, 2002. Sobre el segundo, estoy a punto de concluir una larga investigación. 
2a. Sala

N 978. lib. ${ }^{\circ}$. ${ }^{\circ}$. $15 \mathrm{I}$

Srio. Paredes

[En la parte inferior de la misma portada, se añadió la siguiente inscripción, evidentemente luego de que la investigación se dio por terminada.]

Secretaría del

Senado

$[\ldots]$

Juez el Señor

Galindo

[rúbrica]

[f. Ir $]^{47}$

[grabado]

[f. $2 \mathrm{r}$ ]

Gobierno

del

Distrito Federal

Sección za.

[sello]

[f. 2v]
I3 de enero de $[\mathrm{I}] 830$

Jurado N. I

Enero, ley de I 835

Escribano

$\mathrm{Al}$ archivo

Pastrana
El E. S. Srio. del Despacho de Relaciones en oficio del is del actual, me dice lo que copio="El E. S. Gobernador del Estado de Puebla ha remitido a esta Sría. la adjunta estampa que recibió sin carta que la acompañase el de la Mitra de aquel Obispado, y habiendo dispuesto el E. S. P. para que se pase a V. S. para que por ese Gobierno se practique la averiguación correspondiente en solicitud del origen y circunstancias que pueden descubrirse sobre el citado hecho, tengo el honor de verificarlo con tal objeto, y lo traslado a $\mathrm{V}$. acompañándole la estampa que se menciona para que de toda

47. El documento tiene una doble foliación que no es coincidente: una escrita directamente a mano y otra en números hechos con sellos. En la foliación hecha con sellos hay omisiones, es decir fojas que, por error, o no fueron foliadas o no se consideraron al hacer el conteo. Por lo tanto, decidí utilizar únicamente la foliación manuscrita que, por el contrario, no tiene ningún salto ni error y sí abarca todas las hojas. Por otro lado, es importante aclarar, respecto a la transcripción, que he respetado la puntuación, he modernizado la grafía y he desatado muchas de las abreviaturas con el fin de ofrecer al lector una lectura más fluida. 
[f. $3 \mathrm{r}$ ]

preferencia haga las averiguaciones necesarias a fin de saber la oficina en que se haya grabado la lámina; particularmente, en la del S. Coronel Don Alejandro Valdés, dando cuenta a este Gobierno cada tercer día con los adelantos.

Dios y libertad

México, agosto I8 de I829.

J. M. Tornel

[rúbrica]

S. Juez de Letras

Don Pedro Galindo

[f. $4 \mathrm{r}$ ]

México, agosto I8 de I829.

Acúsese el recibo, avísese a la Suprema Corte de Justicia, cúmplase lo determinado por el Supremo Gobierno, haciéndose la averiguación correspondiente, evacuándose todas las citas que resulten y pasándose desde luego a que Don Alejandro Valdés, y algunos de sus principales dependientes manifiesten las láminas que haya en la Imprenta y digan según la letra de la inscripción si presumen de qué imprenta pueda haber salido o lo que sepan sobre el particular. Lo proveyó el Señor Juez y firmó, doy fe.

$\begin{array}{ll}\text { Galindo } & \text { Juan Fortunato Pastrana } \\ \text { [rúbrica] } & \text { Escribano Nacional } \\ & \text { [rúbrica] }\end{array}$

Razón En diecinueve del mismo agosto, se contestó el recibo al Señor Gobernador del Distrito Federal, y en constancia pongo esta razón.

Pastrana

[rúbrica] 
[f. $4 \mathrm{v}]$

Otra

Inmediatamente se avisó a la Suprema Corte de Justicia de la formación de esta averiguación y en constancia pongo la presente.

\section{Pastrana}

[rúbrica]

Declaración de D. Enseguida, el Señor Juez asociado de mí el escribano pasó a la imJ. M. Gallegos

[f. $5 \mathrm{r}$ ] prenta del señor D. Alejandro Valdés, y siendo en ella presente su administrador, Don José María Gallegos que así expresó llamarse, y para que declare se le recibió juramento que hizo en forma, bajo del cual ofreció decir verdad en lo que fuese preguntado, y siéndolo por sus generales asentó llamarse como va dicho, ser natural y vecino de esta ciudad, casado, mayor de treinta años, $y$ vivir en la calle de Chiquis núm. 8, y siéndolo sobre los particulares de esta averiguación = Dijo: que láminas no tiene ningunas que presentar porque no las hay pues que lo que tiene sólo son escudos pues es diferente la imprenta que grabar láminas.

Puéstole de manifiesto la estampa con que da principio esta sumaria, y preguntádole en que parte se grabaría =Dijo que el día veinte y nueve del presente próximo pasado julio que estuvo en la Imprenta el autor del Toro, que entonces trajo o le presentó varias estampas de las mismas de la que se le ha presentado para que en cada ejemplar de dicho Torito se diera una, y en efecto se han expendido los ejemplares con su estampa, mas ignora quien las haya grabado y sólo se presume que el autor del Torito será quien lo sepa, con lo que se concluyó esta declaración que firmó con el Señor Juez de que doy fe.

Galindo

Juan F. Pastrana

José María Gallegos

[rúbrica]

[rúbrica] [rúbrica]

Razón

En la tarde del mismo día se libró ésta al grabador Torreblanca para que comparezca a declarar al instante, lo que asiento para constancia.

Pastrana

[rúbrica] 
[f. $5 \mathrm{v}$ ]

Declaración de D. J. Inmediatamente compareció ante el Señor Juez el ciudadano Mariano Torreblanca José Mariano Torreblanca que así expresó llamarse, ser originario de Puebla y vecino de esta ciudad, casado, grabador principal de la Casa de Moneda de este Distrito, de treinta y ocho años de edad, que vive en la Calle de la Acequia [tachado Ave María] núm. 22, contigua al Colegio de Santos; para que declare se le recibió juramento que hizo en forma bajo del cual ofreció decir verdad en lo que fuere preguntado; y siéndolo sobre si en su casa se grabó la lámina de la estampa que en este auto se le manifiesta, quién fue el sujeto, y cuánto le dieron por ella =Dijo: que él mismo la hizo, y que la graduó en diez pesos; y que el que se la mandó hacer fue D. Rafael Dávila autor del Torito; pues siendo un artesano el que declara, aunque tiene sueldo, éste no le alcanza, y entre las varias obras que le [tachado ca] llevan de la calle, cogió el de hacer la lámina que tiene dicha; y que cuanto tiene dicho es la verdad en virtud del juramento que tiene [la declaración continúa en la foja Ior]

[ff. 6-9] [Aquí, en mitad de la declaración de Torreblanca, y con los folios señalados, se inserta el número del periódico El Toro redactado por Rafael Dávila, para el que la imagen fue mandada grabar, y cuyo original se conserva también en la Hemeroteca Nacional $]^{48}$

[f. Ior]

hecho en que se afirmó, ratificó y firmó con el señor Juez, doy fe. $=$ Entre renglones $=$ número $22=$ vale $=$ testado $=A v e$ María $=\mathrm{ca}=$ no vale

Galindo José Mno. Torreblanca

[rúbrica] [rúbrica]

48. Título, subtítulo y datos sobre la suscripción aparecen en el propio encabezado y son: $E l$ Toro, "Siguen las hijas del Cojo retozando en el Parián. Diálogo tercero entre un cohetero y un tamborilero". Las suscripciones son de cuatro reales que se darán adelantados por cuatro pliegos mensuales que se llevarán a las casas de los suscriptores, dándoles gratis el aumento que suelan sacar algunos números. Se reciben en la misma oficina en el despacho de arriba y en las alacenas de don Domingo Llanos, portal de Mercaderes, cajón número 25, junto a la casa número 3. 
Juan F. Pastrana

[rúbrica]

México, agosto I9 de I829.

Agréguese el periódico titulado el toro Diálogo tercero en que se hace relación de la estampa, y avísese al Sr. Gobernador del Distrito Federal insertándole la presente declaración con la cual parece se ha cumplido lo que se me previno de que se averiguara la oficina en que se haya grabado la lámina. Así lo mandó y firmó el Sr. Juez, doy fe.

Galindo Juan F. Pastrana

[rúbrica] [rúbrica]

Agregación del Enseguida se entregó por el S. Juez un ejemplar del toro diáloimpreso go $3^{\circ}$ que rubricado de mi puño queda agregado, y en constancia pongo esta razón.

\section{Pastrana \\ [rúbrica]}

[f. IOv]

Razón Consecutivamente se dio parte a la primera Sala de la Suprema Corte de Justicia de la formación de esta causa. Para su constancia pongo esta razón.

\section{Pastrana \\ [rúbrica]}

Otra En veinte y uno del mismo agosto se recibió el oficio, que sigue agregado, en el que se expresa que le ha tocado en turno esta causa a la segunda sala. Para su constancia pongo esta razón.

Pastrana

[rúbrica] 
Idem En veinte y dos del mismo se recibió el oficio de contestación del Sr. Gobernador del Distrito Federal, que con el decreto de su margen sigue agregado a la vuelta del Sr. Secretario de la Segunda Sala. En su constancia pongo esta razón.

\title{
Pastrana
}

[rúbrica]

[f. IIr]

Secretaria de la Ia. Sala

De la Suprema Corte de Justicia

[sello]

Por el oficio de V. de ayer, se ha enterado la Suprema Corte de Justicia de haber recibido orden del Supremo Gobierno, por conducto del Sr. Gobernador del Distrito, para que haga averiguación en qué imprenta pudo estamparse una lámina, que representa irónicamente los progresos de la República Mexicana, de que se remitió una estampa sin carta al Sr. Gobernador de la Mitra de Puebla; y habiendo tocado por turno a su 2a. Sala, se lo comunico para que en lo sucesivo se entienda con ella en lo relativo a este asunto.

Dios y libertad. México, agosto 20 de I829.

\author{
Mariano Aguilar y López \\ Secretario \\ [rúbrica]
}

Sr. Juez de letras

Don Pedro Galindo

[f. I2r]

Gobierno del Distrito Federal

Sección 2 a.

[sello] 
México, agosto 23 de 1829

Agréguese a su

causa, y dése cuenta

Galindo

(rúbrica)

[f. IIv]
He recibido el oficio de V. fecha de ayer el que me ha impuesto de que D. Rafael Dávila es el autor de la lámina que irónicamente representa el estado de la República; en tal virtud, si juzgare de criminal el hecho, espero proceda contra quien resulte culpado. Lo dejo a V. en contestación.

Dios y libertad

México, agosto 2I de I829.

J.M. Tornel

[rúbrica]

S. Juez de Letras

Don Pedro Galindo

[f. I3r] [Mé]xico y agosto 25 de I829

Visto el precedente oficio del Sr. Gobernador del Distrito, no juzgando el presente Juez criminal el hecho de haberse abierto la lámina y circulado las estampas, suspéndase todo procedimiento, dándose cuenta previamente a la Segunda Sala de la Suprema Corte de Justicia, y según las resultas se avisará al Sr. Gobernador del Distrito. Lo proveyó y firmó el Sr. Juez. Doy fe.

$\begin{array}{ll}\text { Galindo } & \text { Juan F. Pastrana } \\ \text { [rúbrica] } & \text { [rúbrica] }\end{array}$

[f. I4r] México, septiembre siete de mil ochocientos veinte y nueve.= Señores Presidente Salgado= Ministros Godoy= Guzmán= Vista: Devuélvase estas diligencias, al Juez inferior, para que formalizando el proceso que corresponde, lo determine conforme a derecho. Lo firmaron=Salgado $=$ Godoy $=$ Guzmán= José María Paredes Srio.

Es copia del original que queda en esta Secretaría de mi cargo.

México nueve de septiembre de mil ochocientos veinte y nueve.

José María Paredes

Secretario

[rúbrica] 
México, septiembre II de I829

Cúmplase lo determinado por la Suprema Corte de Justicia: notifíquese a Don Rafael Dávila que dé fiador de su persona dentro de veinte y cuatro horas, y cítesele para declarar en mi casa mañana a las cuatro de la tarde. Lo proveyó y firmó el Sr. Juez. Doy fe

$\begin{array}{ll}\text { Galindo } & \text { Juan Fortunato Pastrana } \\ \text { [rúbrica] } & \text { [rúbrica] }\end{array}$

Se libró inmediatamente ésta a D. Rafael Dávila para que comparezca mañana a casa del S. Juez a declarar lo que asiento para constancia.

\section{Pastrana \\ [rúbrica]}

En doce del mismo septiembre

[f. I4v]

del corriente año, siendo presente D. Rafael Da [entre renglones] en la casa del Sr. Juez, le hice saber yo el escribano el auto anterior, $\mathrm{y}$ entendido $=$ Dijo

No pasó. Pastrana

[rúbrica]

En doce del mismo septiembre del corriente año, yo el escribano, siendo presente en la casa del Sr. Juez Don Rafael Dávila, le hice saber lo mandado en el anterior auto, y entendido =Dijo: que cumplirá con lo prevenido por el señor Juez en cuanto a dar el fiador de su persona dentro de veinte y cuatro horas; pero que indica al referido Sr. Juez que debiendo recaer algún acuerdo sobre el particular de la lámina y contando por la declaración del grabador Torreblanca que el que habla se la mandó abrir, no por esto es cierto que él es el autor de ella, ni el que por sí la mandó abrir, pues sólo ha sido un comisionado, esto expuso y firmó, doy fe 


$\begin{array}{ll}\text { Rafael Dávila } & \text { Juan Fortunato Pastrana } \\ \text { [rúbrica] } & \text { [rúbrica] }\end{array}$

[f. I5r]

Secretaria de la 2a. Sala

de la Suprema Corte de Justicia

[sello]

Devuelvo a V. [?] la causa formada sobre averiguación de quien haya grabado una lámina, para los efectos que expresa el Supremo auto de 7 del que rige acusándome su recibo.

Dios y ley México

9 de septiembre de 1829 .

José Ma. Paredes

Srio.

[rúbrica]

Sr. Juez de letras, Lic. Don

Pedro Galindo

[f. I6r] La misma tarde del día de hoy doce del corriente septiembre, siendo presente ante el Señor Juez D. Rafael Dávila para que declare, se le recibió juramento que hizo en forma, bajo del cual ofreció decir verdad en lo que supiere y fuere preguntado, y siéndolo por su nombre y generales asentó llamarse como queda asentado, ser originario y vecino de esta ciudad, casado con Doña Agustina Avendaño, que es comerciante y salitrero con una fábrica en la ciudad de Texcoco [Tescuco en el original], de cuarenta y dos años de edad, y que vive en la calle de Manzanares casa núm. 2. Preguntado con arreglo a lo que resulta de la declaración que obra a foja 5 vuelta de Don José Mariano Torreblanca= Dijo: que es cierto haber solicitado a D. Mariano Torreblanca, como el más hábil de los grabadores para que abriera la lámina con alusión a lo que lee en el Diálogo $3^{\circ}$. Titulado el Toro; pero que esto lo hizo como ya tiene dicho, por encargo del autor de dicho Diálogo, 
236

[f. I6v]

[f. I7r]

[f. I7v]
HELIA BONILLA

pues aunque se lo atribuyen al que habla, es una conjetura infundada pues puede probar legalmente no tener parte en el citado Diálogo. Preguntado, quién es el que le encargó que se abriera la lámina= Dijo: que el que le encargó mandar a abrir dicha lámina, fue el autor del Toro; y que previniendo la ley de libertad de imprenta en el artículo veinte de su título séptimo, que ninguna autoridad podrá obligar a que se le haga manifiesto el nombre del autor o editor de un impreso, sin previa acusación y declaración del primer Jurado de haber lugar a formación de causa; y siendo esta lámina parte del impreso, suplica al señor Juez le mande al que habla por un auto por escrito declare quién es el autor para resguardo del que responde.

En este acto el señor Juez, le hizo entender a D. Rafael Dávila, que lo que se trata averiguar, no es el autor del Torito, sino el de la lámina, y que aun cuando quiera suponer que la lámina es un incidente del papel titulado el Toro, el privilegio de no indagar quién es el autor, recae sólo sobre escritos impresos, y no sobre láminas, ni caricaturas, por lo cual, y haber mandado el Supremo Gobierno averigüe quién es el autor, y prevenido por la Corte Suprema se perfeccione la causa y se determine en justicia se le apercibe declare quién fue quien le encargó la apertura de la lámina, entendido que de no declarar se tomará la providencia que corresponde= Dijo: que tiene ya insinuado que la lámina pertenece al impreso que el autor de ella es el del referido Diálogo quien no ha hecho otra cosa que seguir el ejemplo de todos los autores que abren láminas de lo más notable de sus obras a los que jamás se les ha juzgado por separado las láminas de sus escritos, por lo que, y en atención al artículo ya citado de la ley de libertad de imprenta, no se cree obligado el que habla a declarar quién es el autor de dicha lámina, y por lo mismo, apela (hablando debidamente) de este apercibimiento.

Preguntado cómo supo lo que consta en la declaración de Torreblanca según dijo en la notificación que se le hizo del auto que antecede= Dijo: que el mismo Torreblanca se lo manifestó el propio día que vino a declarar ante el presente señor Juez: con lo que se concluyó esta declaración que quedó abierta para continuarla siempre que convenga y firmó con el señor juez, doy fe. 


$\begin{array}{ll}\begin{array}{l}\text { Galindo } \\ \text { [rúbrica }]\end{array} & \begin{array}{l}\text { Rafael Dávila } \\ \text { [rúbrica }]\end{array} \\ & \text { Juan F. Pastrana } \\ & {[\text { rúbrica }]}\end{array}$

[f. $18 \mathrm{r}]$

México, septiembre I4 de I829

Pasada la visita general del día de mañana, remítase esta sumaria a la Segunda Sala de la Suprema Corte de Justicia. Lo proveyó y firmó el señor Juez doy fe

$\begin{array}{ll}\text { Galindo } & \text { Juan Fortunato } \\ \text { [rúbrica] } & \text { Pastrana } \\ & \text { [rúbrica] }\end{array}$

[f. I9r]

México septiembre veinte y dos de mil ocho cientos veinte y nueve.= Señores presidente Salgado $=$ ministros Godoy= Guzmán $=$ Vista esta sumaria instruida con averiguación del responsable, de una caricatura injuriosa a la República: el apercibimiento impuesto por el Juez de letras Lic. D. Pedro Galindo para que D. Rafael Dávila declare quién le encargó la apertura de la lámina de la referida caricatura, en consideración a que a los interesados se debe conservar la libertad que tienen para especificar y probar sus excepciones, se revoca el indicado apercibimiento: en consecuencia devuélvasele la sumaria al citado Juez para que proceda a lo que haya lugar. $Y$ lo firmaron $=$ Salgado $=$ Godoy $=$ Guzmán = Por ocupación del Secretario Lic. Manuel de la Barrera oficial mayor.

Es copia del original que queda en esta Sría de mi cargo. México, veinte y dos de septiembre de mil ocho cientos veinte y nueve.

José Ma. Paredes

Secretario

[rúbrica]

México, septiembre 24 de 1829

Cúmplase lo determinado por la Suprema Corte de Justicia, acúsese el recibo, y notifíquese a D. Rafael Dávila que en el 
preciso término de seis días y en uso de la libertad que tiene para especificar y probar sus excepciones, lo verifique con la relación a lo que tiene dicho en su declaración, dando previamente la fianza que se le previno. Lo proveyó y firmó el señor Juez, doy fe.

$\begin{array}{ll}\text { Galindo } & \text { Juan F. Pastrana } \\ \text { [rúbrica] } & \text { [rúbrica] }\end{array}$

Razón

En veinte y ocho del mismo, se acusó el recibo, lo que asiento para constancia.

\section{Pastrana \\ [rúbrica]}

Solicitud a

D.

D. R. Dávila
En el mismo día yo el escribano habiendo pasado a la casa de Rafael Dávila, y preguntado por éste a una señora, que contestó no hallarse en ella y no tener hora fija en que poderse encontrar, lo que asiento por diligencia, de que doy fe.

\section{Pastrana \\ [rúbrica]}

México, septiembre 28 de I829.

Vista la diligencia anterior. \$ 